Uploaded : January 2021

Accepted : June 2021

Published : June 2021

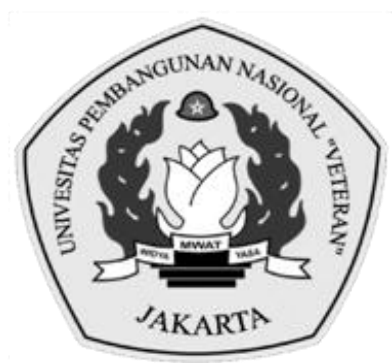

\title{
USAGE OF BLOCKCHAIN TO ENSURE AUDIT DATA INTEGRITY
}

\author{
Tony Wibowo ${ }^{1 *}$, Yefta Christian² \\ 1tony.wibowo@uib.ac.id, 2yefta@uib.ac.id \\ 1,2Universitas Internasional Batam, Indonesia \\ *corresponding author
}

\begin{abstract}
Usage of technology to help finance audit process is not a new instance. But since the rise of 4th industrial revolution and emergence of smart technology relatively in a short period of time, adopting technology have its challenges and drawbacks. Data integrity has been an issue for finance audit process because digital data is easy to tamper. This condition makes audit process become difficult and potential of audit fraud is high. In this study we would like to explore usage blockchain technology as future database engine for Accounting Information System (AIS) through literature review on past study regarding usage of Blockchain database engine in Auditing. Blockchain as a technology relatively unheard before cryptocurrency albeit its advanced technology in data storage to ensure data integrity. We will explore the advantages and risk in adopting blockchain as well as current state of academics and technology regarding blockchain adoption. From the findings we formulate recommendation to realize usage of blockchain technology in a more accessible manner.
\end{abstract}

Keywords: Blockchain; Data Integrity; Audit.

\begin{abstract}
Abstrak
Penggunaan teknologi untuk membantu proses audit keuangan bukanlah hal baru. Namun sejak munculnya revolusi industri 4.0 dan kemunculan teknologi pintar yang relatif dalam waktu singkat, mengadopsi teknologi memiliki tantangan dan masalahnya sendiri. Integritas data telah menjadi masalah dalam proses audit keuangan karena data digital mudah dirusak. Kondisi ini membuat proses audit menjadi sulit dan potensi kecurangan audit tinggi. Dalam studi ini kami ingin mengeksplorasi penggunaan teknologi blockchain sebagai sistem basis data masa depan untuk Sistem Informasi Akuntansi (SIA) melalui peninjauan pustaka studi sebelumnya terkait penggunaan teknologi basis data Blockchain dalam audit. Blockchain sebagai teknologi yang relatif belum pernah terdengar selain cryptocurrency meskipun teknologi canggihnya dalam penyimpanan data untuk memastikan integritas data. Kami akan mengeksplorasi keuntungan dan risiko dalam mengadopsi blockchain serta keadaan akademis dan teknologi saat ini terkait adopsi blockchain. Dari hasil yang ditemukan, kami memberikan tindakan rekomendasi untuk merealisasikan penggunaan teknologi blockchain dengan mementingkan aksesnya yang lebih mudah.
\end{abstract}

Kata Kunci: Blockchain; Integritas Data; Audit. 


\section{INTRODUCTION}

The term audit is referring to a financial statement audit, which is an examination and evaluation of the financial statement from an organization objectively by groups of individuals (auditors). Financial statement audits aim to ensure there is no material misstatement in the report and ensure the financial reports are accurate to reflect the organization's operation. Audit is normally conducted internally but to ensure the credibility of audit result, it is often executed and verified by external auditor. Contrary to what public believe of audit result, clean audit opinion is not directly translated to be clean financial statement, but it means that the auditor has not identified any fraudulent and misstatement in the financial statement (Carindri \& Untara, 2019). Auditors expressed the audit opinion to obtain reasonable assurance, not as absolute confidence, which is align with audit's purpose. According to International Financial Reporting Standards (IFRS), purpose of financial audit is to enhance the degree of confidence in the financial statement. Absolute certainty cannot be provided by audit report because it is impossible to detect each and every human error since it required the auditor to check every transaction, which at a time considered waste of resource and time (Barta, 2018). This is why technology is brought up to solve this problem.

The Emergence of IT already been predicted to change the world and how it works since its inception. With IT adoption spawned new business approaches and new business models. The so-called "start-ups" that utilized smart technology and innovative usage of technology are truly changing the world. Accounting and audit process need to change to adopt such technology to stay relevant (Rezaee et al., 2001). Today in second decade of $21^{\text {st }}$ century technological advanced already pushed humanity beyond what we achieve in the last century. Hundreds of thousands of devices connected seamlessly generating data points that we humans with our primitive brains no longer able to process the data collected faster than electronic brain. Artificial Intelligence already changes the game field so vast that we humans are soon too obsolete. There is no doubt that the accounting and auditor's profession will soon change because of the digital revolution we currently in. There are no longer need to long hour of examining transaction record where it can be digitalized and check almost instantly by using sophisticated information system. Auditors position will be shifting to relay in key point and important information to share the audit result in clear way (Kruskopf et al., 2020; Soeprajitno, 2019).

Example of technology usage in financial audit can be traced back to the end to $20^{\text {th }}$ century but with rising technological advanced, what are those conceptual ideas can only be realized and used in real practice in recent time. Research by Claudiu, Muntean, \& Didraga, (2018) are mentioning ideas about how to utilize big data and machine learning in finance audit. They posit that through text mining to help auditors run through meeting notes, management reports and other documents. Auditor can even experience the business environment in a more holistic and comprehensive manner. Not to mention that that ability also unlocks the possibility to identify all data points that have significant impact on client's business. Usage of machine learning also enabled auditor to formulate the data in visual that are easier to detect fraud and inconsistency in financial audit. Another research by Dbouk \& Zaarour, (2017) mention usage of machine learning to detect 
Earning Manipulation Detection. Computer generalized the knowledge to detect fraudulent data from previous observation. By combining detection by computer assisted technique and manual by auditor, it's possible for a machine to detect and recognize fake data to make financial statement looks healthy.

Since early of digital data inception, most of business around the world no longer use manual data and bookkeeping. Even the terms "bookkeeping" is now transformed into how to manage data entry of daily activity. Relational database system, one of the most solid phase of data management technology is widely used in all levels of businesses and we can safely say that it is unthinkable for businesses not to have amasses of data that define the business. With the increase of data in either quantity or quality, tandem with data connectivity and multiple platforms that today's businesses need to engage to stay in front pack of global competition. Classic Database Management System was no longer capable to store and manage such data. Usage of cloud and noSQL become necessity for business to store their immense data. Business must transfer their data in form of relational database to a more fluid form to host the data from numerous data sources (Fouad \& Mohamed, 2020). When we are faced with large clump of data that interconnected to one another and an intricate web of relationships one must think that such data can't be manipulated. But like all system, there are always vulnerability. Even if by today technology there are no technology capable to manipulate big data like we manipulate earning data, it does not mean that it will never come true. The idea of data integrity in the era of big data is becoming more prevalent.

The idea of data integrity itself come from three (3) quality standard of information systems: Confidentiality, Integrity and Availability. Those three characteristics have already become synonymous with IT Framework and used to dictate how well IT Governance is being executed in one's business. More even so in cloud infrastructure, big data and AI being adopted here and there. There is an uncertainty in technology where big business entrusts their resources to an unseen infrastructure. There is an uncertainty in a large clump of data that are generated from unseen sources. There are uncertainties in decision developed from data communicated between machines that seems bypass human judgment. Those uncertainties are not breach of confidentiality. Confidentiality already compromised with adoption of big data in form of social media and transfer of data to cloud, that are not managed under jurisdiction of own confidentiality. Because of internet and today's network technology, data availability is no longer an issue, as long as you have connection you can access your data whenever and however you want to. The only parameter that need to be concerned is again: data integrity (Shabir et al., 2016; Tchernykh et al., 2019).

In the year 2020, the world faced with a global event that push the technology adoption a decade in the future. COVID-19 pandemic is one of the longest and worst biological disaster that struck today's community and driven almost all business to dust and open the world with impending doom of global depression and recession. But to a more resilient business and those who adopt the usage of technology that enabled them to operate without worry about social distancing, business was tough but manageable (Seetharaman, 2020). Audit process during pandemic also impacted, with limitation of transportation, audits, like many other activities, must be done remotely. Since it was done not in person 
and auditor only able to perform audit based on access on data given to him/her. This brings some concerns like transparency and uncertainty in auditor's opinion. But the real problem is the glaring question of every auditor: "Is the data truthful?" This study is a literature review aims to introduce a technology that will help auditor to have assurance of data integrity: Blockchain.

\section{LITERATURE REVIEW}

Stuart Haber and W. Scott Stornetta first discovered the series of blocks equipped with cryptography. Several years after the discovery of blockchain was first conceptualized by Satoshi Nakamoto. Blockchain technology is a storage technology in the form of blocks that can be distributed peer to peer. Each block is encrypted and can be seen by all interested parties to be safe when distributed. Blockchain can be likened to a ledger that is able to record large-scale transactions and store each record securely with encryption.

Blockchain has a unique data structure and organization with the following four (4) characteristics: Decentralization, Non-Tampering, Traceability and Transparency. One of the basest ideas of blockchain technology is distributed ledger and database system that are not correlated in any form of dependency but stand alone and use to acknowledge record in other database. Blockchain take the idea and run with concept of database warehouse, one of the earliest attempts of developing time variant and non-volatile database system and create a nontampering policy as defining feature of blockchain (Chowdhury et al., 2018). Furthermore, using link-list technology, all record entry and changes can be trace to its original inception, this technology also featured in almost all modern database engine. But combined with decentralization and non-tampering technology, this create a distributed database that are virtually impossible to be cracked and manipulate beyond the legal way. The encapsulation of blockchain that promote data integrity also fully supported with transparency that allow all people with internet connection and permission can check it 24/7 (Wang et al., 2017).

Figure 1. Blockchain Structure

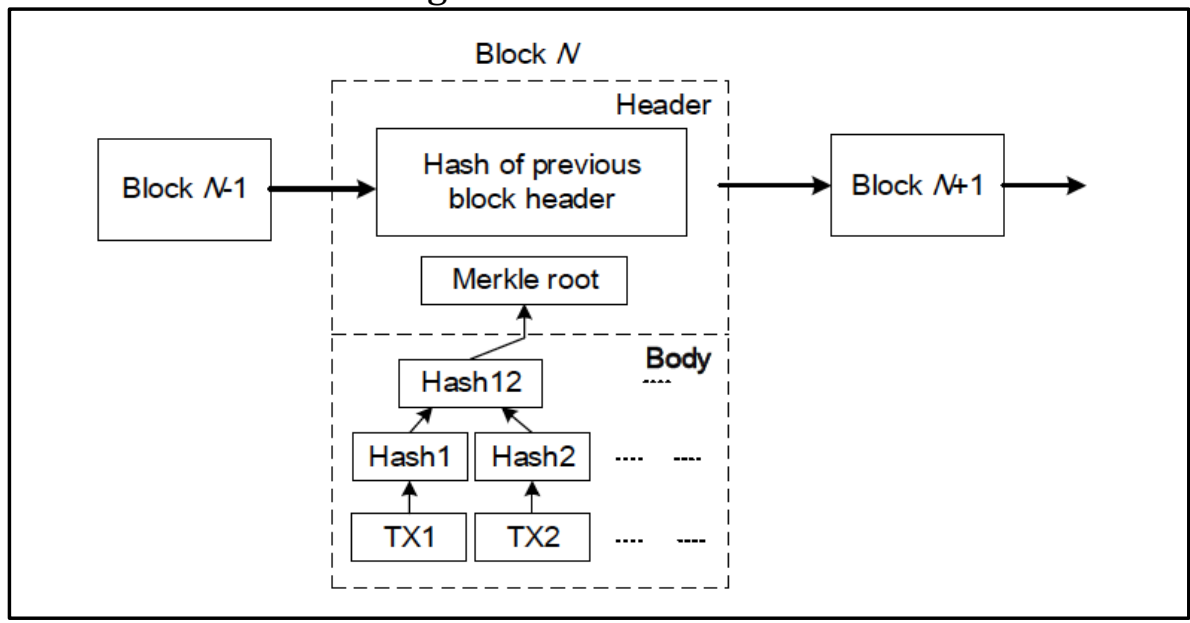

Source: Wang et al., (2017) 
The characters that exist on the blockchain are a reason to ensure data integrity. The integrity of data on the blockchain is ensured by encryption in the form of hashes. Hash ensures data integrity by locking data from any unknown parties. The hash value of each data that belongs to the blockchain is unique and cannot be manipulated. Algorithms on the blockchain are still being developed today to strengthen the level of security (Nofer et al., 2017). At present, the type of blockchain can be divided into three types, namely public blockchain, consortium blockchain and private blockchain. The public blockchain allows every node on the blockchain to be involved in every process that occurs, whereas on the private blockchain only nodes that have authorization from a predetermined organization can be involved in the existing process, unlike the blockchain consortium, there are several nodes that can determine the existing processes outside of the predetermined organization (Zheng et al., 2017). For more details, see Table 1 below:

Table 1. Comparison between Public Blockchain, Consortium Blockchain and Private Blockchain

\begin{tabular}{|c|c|c|c|}
\hline Property & Public Blockchain & Consortium & Private Blockchain \\
\hline Consensus & All Miners & Selected set of nodes & One organization \\
\hline Determination & & & \\
\hline Read permission & Public & $\begin{array}{l}\text { Could be public or } \\
\text { restricted }\end{array}$ & $\begin{array}{l}\text { Could be public or } \\
\text { restricted }\end{array}$ \\
\hline Immutability & $\begin{array}{l}\text { Nearly Impossible to } \\
\text { tamper }\end{array}$ & Could be tampered & Could be tampered \\
\hline Efficiency & Low & High & High \\
\hline Centralized & No & Partial & Yes \\
\hline Consensus process & Permissionless & Permissioned & Permissioned \\
\hline
\end{tabular}

Source: Zheng et al., (2017)

Speaking of blockchain, we are not releasing it from data storage and cryptography. Data storage and cryptography contained on the blockchain are the reason for being a blockchain due to the use of cryptocurrency, which is often known as bitcoin. With the blockchain currency transactions can be carried out safely without the need for interference by trusted authorities, blockchain currency transactions will avoid double-spending (Yano et al., 2020).

In usage, blockchain is very closely related to the digital currency, but that does not mean its use is only for that; blockchain is often used as a database. The use of blockchain as a database serves various purposes, but the primary purpose of choosing blockchain as a database is its distribution flow and data security. The most widespread use of blockchain as a database is as a distributed replicated database. Blockchain can be used as a database for IoT. Blockchain is used as a database for IoT because it has two critical factors that form a database on an IoT system, namely latency, and consistency. In addition to the database itself, the Bitcoin Backbone Protocol is also applied to the database, and the result is that the type of database can be used to perform simple computing on IoT (Tseng et al., 2020). The use of blockchain as a database has also proven to be better than traditional databases. Blockchain, when compared to conventional databases has advantages, especially in its data storage capabilities. Data stored via blockchain 
can be stored for much longer than conventional databases so that existing data can be more productive (Chowdhury et al., 2018).

The use of blockchain as a means of managing fintech is very common currently. The financial authorities in their respective banks choose to use blockchain because of its advantages in various ways. Data security, ease of transparent transfer and allowing the absence of intermediaries at the time of transactions are blockchain advantages that are indispensable in fintech management. In addition, many experts say that blockchain can be a solution for developing country economies and all the activities in them. Blockchain is predicted to help developing countries manage assets, manage financial flows, regulate distribution channels and all other activities related to the economy in that country (Underwood, 2016).

To sharpen the business and financial side of an ongoing business and industry blockchain is needed. Even so, in 2020 there are still quite a lot of world financial industries that have not taken advantage of blockchain. The need to use blockchain in the financial industry has begun to be realized and the trend is increasing from year to year, as evidenced by the increasing number of searches for data about blockchain on Google (Ali et al., 2020). The fear that often arises from financial actors is that financial actors are unfamiliar with this system, not to mention the absence of clear standards, security, scale coverage and several other things. The transition process from the traditional approach from what has been done by financial actors to the blockchain may not be easy and smooth, but to keep up with and keep up with the existing competition blockchain is very necessary.

There are several main reasons why blockchain is so necessary. One of the first and foremost are enforcing and ensuring data integrity in the whole data. The technology and enforcing non-tampering technology and transparency allow all data to be fully secured. All tampering, if there a tampering, will detected and corrected almost automatically by the combination of multiple database confirmation and traceability technology. The assurance of data integrity will be the foundation of trust between all parties, for corporation, especially those is B2B business value trust more that monetary gain. In long term, for government, this will build a strong trust to government integrity and ensuring the end of corruption. The only way blockchain is failed to deliver those values are technical failure, which can be occurred in any technology. But that problem can be solved and $100 \%$ prevented with proper maintenance. Another case will be malicious peers, usually malicious activities that are carried out cannot be predicted and spoil everything (Drescher, 2017). Data integrity is an absolute value in the use of blockchain. To ensure the successful adoption of blockchain technology, we must make sure that each party distributes data properly and does not carry out activities outside of what has been agreed upon.

\section{RESEARCH METHODOLOGY}

In this study, we employed literature review methods by gathering all past studies about usage and application of blockchain technology in auditing process. All articles must be published in a good reputation journal or conference 
proceedings either indexed in SINTA for Indonesian articles or Indexed by respected organization for international articles. After gathering those articles, we will analyze each theories, findings and implementations and present that findings in 2 parts: Blockchain technology and the usage of Blockchain technology in audits. The goals of this study are to summarize the Blockchain technology usage in audit and recommend steps to adopting blockchain technology in Indonesia.

\section{RESULT AND DISCUSSIONS}

Blockchain technology as database engines for business to replace current database engine is still not widely used in Accounting Information System (AIS). Past experiments show that blockchain can be implemented in accounting environment and relatively fit in with the system of no editing can be done whatsoever in the record except by applying the entry correction on GAAP (Dai \& Vasarhelyi, 2017). Another study state that usage of blockchain technology to record transaction with cryptographic audit trail that maintained and validated by multiple nodes will immensely change the industry. This disruptive technology if implemented correctly will solve the question of data integrity and the statement that data of audited entity is easy to be tampered (Wei \& Ding, 2018).

As we already explain in nature of blockchain technology previously, it is imperative to outline the benefits of having blockchain as database engine. By using blockchain to store data, especially transaction data, it will give assurance to external auditor and investor to the robust data integrity in our system. Moreover, it also removes the threat of data theft, data tampering and data loss due to the nature of Distributed Ledger Technology (DLT) and smart contracts: the two cores of blockchain technology. For auditors, usage of timestamp that shown the data chronologically and thus make financial audit work become more efficient. The distributed storage system makes every node can verify and validate each record and reduces furthermore audit process cost. Tandem with data mining and artificial intelligence, presence of auditor is more as audit result communicator since the process is almost automatically. Even by itself, blockchain database will ensure finance data integrity and that is a huge advantage as it will remove doubt on financial statement report (Osmani et al., 2020; Tan \& Low, 2019; Wei \& Ding, 2018). With such overwhelming advantages, it raises a question of why it's not widely used, why today database is not changing its engine to blockchain and adopt such technology?

Cost efficiency and cost reduction will be the main issue to the decision of adopting blockchain technology. The cost of operating blockchain engine database in large organization can be classified to 3 main factors: Transaction Cost, energy cost and storage cost. Which comparing to distributed database and cloud engine, implementing blockchain engine could potentially cost much more. For older organization, transition to cloud is a logical decision since they already have the solid and aging infrastructure, it will cost efficient to transfer their data, platform and even infrastructure to cloud technology to change their obsolete one. Startups and hi-tech business never have infrastructure of their own and embracing cloud technology in the first place. But to change to blockchain it means that organization 
need to invest on some semblance of infrastructure as platform of blockchain. Cryptocurrency is by far the only globally successful usage of blockchain because of open data policy adopted by cryptocurrency. It is a very different story with organization financial data. Another turn off is most of current AIS are not capable to handle blockchain database engine and thus it must be re-develop to host blockchain database engine (Osmani et al., 2020; Valdeolmillos et al., 2020). But if those issue are solved; it will pave the blockchain technology as new standards of database engine. Latest study shows that by introduce Proof of Phone into Proof of Work and Proof of Stake platform to use computational capabilities of smartphone could potentially reduce the operation cost up to $98.2 \%$ compared to conventional blockchain platform (Kim et al., 2019).

Blockchain has been proven to produce structured, neat and transparent financial management so that blockchain is proven to be superior for business use and auditing, but how is the handling of the security side of a blockchain. Data stored on the blockchain allows cyberattacks and the data may be transferred and misused for certain purposes. The practice of taking over and misusing this data is possible because there is open data circulating over the internet and there needs to be a means on the blockchain to deal with this problem. Even so, blockchain has keying and this must be considered by businesspeople and auditors in using blockchain. One of the ways to implement cybersecurity on the blockchain is to ensure that there is a general ledger that produces a definite, safe and accurate count. Guaranteed security makes big financial industry players such as NASDAQ and major world banks decide to use blockchain to support their financial, business and audit processes. Blockchain is very promising in terms of security and for the future security in blockchain will further develop along with the development of technology in the business and auditing fields and has been proven to be able to secure not only safeguarding existing data but also ensuring that every financial process runs properly (Demirkan et al., 2020).

Indonesian-based companies need to think about a lot of aspect regarding adopting blockchain technology. Besides the cost of implementation, one of the more pressing matters is about current data situation. One of the most difficult issues to tackle is to ensure current data in traditional database systems is already have a solid data integrity. Traditional database is easy to be tampered with even simple basic knowledge of database management which make conversion might not solved the issue of data integrity. Another issue to implement block chain to audit process is re-development of existing AIS to support blockchain engine. If Indonesian government want to standardized usage of blockchain, one of the earliest policies need to be implemented is national blockchain network to host database system which will use to house national data from citizenship and tax system. Company can piggyback the system using service-like system to use fraction of national blockchain network. This concept of national blockchain is actually is being developed by countries like Australia, India, China to challenge Japan's supremacy is blockchain adoption (Yano et al., 2020). Usage of blockchain engine still needs to be explored in future studies. 


\section{CONCLUSION}

Audit is one of the most important process in financial management and thus its activity cannot be taken lightly. By introducing technology and digitalization of data, audit process already evolved and a far cry for when its first inception. In the face of 4th industrial revolution where smart technologies are taken over most of mundane job it will soon come to auditing process. But among those advancement, database system technology albeit with introduction of big data technology are not truly embraced in finance environment. This paper suggests the idea of using blockchain technology as database engine to ensure data integrity. Blockchain, as well as other technology need more exploration and refinement to reduce the cost and increase its capacity and capability to work in tandem with other innovative and disruptive technologies. Blockchain adoption as database engine is a new step toward data integrity assurance in financial environment will reduce significantly financial fraud. We also suggest that future auditors need to focus on position themselves as communicator of the audit result and translate the report to be easier to digest and provide added value to what the system already capable of doing so.

\section{ACKNOWLEDGEMENT}

We thank to Dr Iskandar Itan, Dr. Meiliana, Dr. Teddy Jurnali, Dr. Agustina Fitrianingrum and Ria Karina (Accounting Program-Universitas Internasional Batam) to provide chance to submit this article as part of submission from Universitas Internasional Batam. We also thank to Dr. Hendi Sama and Herman for useful insight and discussion.

\section{REFERENCES}

Ali, O., Ally, M., Clutterbuck, \& Dwivedi, Y. (2020). The state of play of blockchain technology in the financial services sector: A systematic literature review. In International Journal of Information Management (Vol. 54, p. 102199). Elsevier Ltd. https://doi.org/10.1016/j.ijinfomgt.2020.102199

Barta, G. (2018). the Increasing Role of It Auditors in Financial Audit: Business,Management and Education, 16(1), 81-93. https://doi.org/10.3846/bme.2018.2142

Carindri, F., \& Untara. (2019). the Effect of Risk, Profitability, and Liquidity on Capital Adequacy. Journal of Business Economics, 24(1), 36-50. https://doi.org/10.35760/eb.2019.v24i1.1854

Chowdhury, M. J. M., Colman, A., Kabir, M. A., Han, J., \& Sarda, P. (2018). Blockchain Versus Database: A Critical Analysis. Proceedings - 17th IEEE International Conference on Trust, Security and Privacy in Computing and Communications and 12th IEEE International Conference on Big Data Science and Engineering, Trustcom/BigDataSE, 1348-1353. https://doi.org/10.1109/TrustCom/BigDataSE.2018.00186 
Claudiu, B., Muntean, M., \& Didraga, O. (2018). Intelligent Decision Support in Auditing: Big Data and Machine Learning Approach. 6(May), 425-430. www.conferenceie.ase.ro

Dai, J., \& Vasarhelyi, M. A. (2017). Toward blockchain-based accounting and assurance. Journal of Information Systems, 31(3), 5-21. https://doi.org/10.2308/isys-51804

Dbouk, B., \& Zaarour, I. (2017). Financial Statements Earnings Manipulation Detection Using a Layer of Machine Learning. International Journal of Innovation, Management and Technology, 8(3), 172-179. https://doi.org/10.18178/ijimt.2017.8.3.723

Demirkan, S., Demirkan, I., \& McKee, A. (2020). Blockchain technology in the future of business cyber security and accounting. Journal of Management Analytics, 7(2), 189-208. https://doi.org/10.1080/23270012.2020.1731721

Drescher, D. (2017). Blockchain basics: A non-technical introduction in 25 steps. In Blockchain Basics: A Non-Technical Introduction in 25 Steps. https://doi.org/10.1007/978-1-4842-2604-9

Fouad, T., \& Mohamed, B. (2020). Model Transformation from Object Relational Database to NoSQL Column Based Database. ACM International Conference Proceeding Series. https://doi.org/10.1145/3386723.3387881

Kim, J. M., Won Lee, J., Lee, K., \& Huh, J. (2019). Proof of Phone: A Low-cost Blockchain Platform. 2019 IEEE International Conference on Consumer Electronics, ICCE 2019, 1-4. https://doi.org/10.1109/ICCE.2019.8662107

Kruskopf, S., Lobbas, C., Meinander, H., Söderling, K., Martikainen, M., \& Lehner, O. (2020). Digital accounting and the human factor: Theory and practice. ACRN Journal of Finance and Risk Perspectives, 9(1), 78-89. https://doi.org/10.35944/jofrp.2020.9.1.006

Nofer, M., Gomber, P., Hinz, O., \& Schiereck, D. (2017). Blockchain. Business and Information Systems Engineering, 59(3), 183-187. https://doi.org/10.1007/s12599-017-0467-3

Osmani, M., El-Haddadeh, R., Hindi, N., Janssen, M., \& Weerakkody, V. (2020). Blockchain for next generation services in banking and finance: cost, benefit, risk and opportunity analysis. Journal of Enterprise Information Management. $\quad \underline{\text { https://doi.org/10.1108/JEIM-02-2020-0044 }}$ https://doi.org/10.1108/JEIM-02-2020-0044

Rezaee, Z., Elam, R., \& Sharbatoghlie, A. (2001). Continuous auditing: The audit of the future. Managerial Auditing Journal, 16(3), 150-158. https://doi.org/10.1108/02686900110385605

Seetharaman, P. (2020). Business models shifts: Impact of Covid-19. International $\begin{array}{llll}\text { Journal of Information } & \end{array}$ https://doi.org/10.1016/j.ijinfomgt.2020.102173

Shabir, M. Y., Iqbal, A., Mahmood, Z., \& Ghafoor, A. (2016). Analysis of classical encryption techniques in cloud computing. Tsinghua Science and Technology, 21(1), 102-113. https://doi.org/10.1109/TST.2016.7399287

Soeprajitno, R. R. W. N. (2019). Potensi Artificial Intelligence (Ai) Menerbitkan Opini Auditor? Jurnal Riset Akuntansi Dan Bisnis Airlangga, 4(1), 560-573. https://doi.org/10.31093/jraba.v4i1.142

Tan, B. S., \& Low, K. Y. (2019). Blockchain as the Database Engine in the Accounting 
System. Australian Accounting Review, 29(2), 312-318. https://doi.org/10.1111/auar.12278

Tchernykh, A., Schwiegelsohn, U., Talbi, E. ghazali, \& Babenko, M. (2019). Towards understanding uncertainty in cloud computing with risks of confidentiality, integrity, and availability. Journal of Computational Science, 36. https://doi.org/10.1016/i.jocs.2016.11.011

Tseng, L., Yao, X., Otoum, S., Aloqaily, M., \& Jararweh, Y. (2020). Blockchain-based database in an IoT environment: challenges, opportunities, and analysis. Cluster Computing, 23(3), 2151-2165. https://doi.org/10.1007/s10586$\underline{020-03138-7}$

Underwood, S. (2016). Blockchain Beyond Bitcoin. Communications of the ACM, 59(11), 15-17. https://doi.org/10.1145/2994581

Valdeolmillos, D., Mezquita, Y., González-Briones, A., Prieto, J., \& Corchado, J. M. (2020). Blockchain technology: A review of the current challenges of cryptocurrency. Advances in Intelligent Systems and Computing, 1010, 153160. https://doi.org/10.1007/978-3-030-23813-1 19

Wang, J., Wang, Q., Zhou, N., \& Chi, Y. (2017). A Novel Electricity Transaction Mode of Microgrids Based on Blockchain and Continuous Double Auction. Energies, 10(12). https://doi.org/10.3390/en10121971

Wei, M., \& Ding, R. (2018). Research on Financial Audit Innovation Based on Blockchain Technology. 113(Sshr 2017), 206-210. https://doi.org/10.2991/sshr-17.2018.36

Yano, M., Dai, C., Masuda, K., \& Kishimoto, Y. (2020). Blockchain Business and Its Regulation. In Blockchain and Crypt Currency (pp. 107-127). https://doi.org/10.1007/978-981-15-3376-1 7

Zheng, Z., Xie, S., Dai, H., Chen, X., \& Wang, H. (2017). An Overview of Blockchain Technology: Architecture, Consensus, and Future Trends. Proceedings 2017 IEEE 6th International Congress on Big Data, BigData Congress 2017, 557-564. https://doi.org/10.1109/BigDataCongress.2017.85 
EQUITY, Vol. 24, No.1, 2021, 47-58

This page is intentionally left blank for fulfillment purposes 